\title{
Pengembangan Kombinasi Produk Olahan Kelor dan Susu Sapi dalam Mencegah Stunting dan Meningkatkan Ekonomi Kader Posyandu Kemuning Lor di Era Covid-19
}

\author{
Maya Weka Santi ${ }^{1 *}$, Cherry Triwidiarto ${ }^{2}$, Theo Mahiseta Syahniar ${ }^{3}$, \\ Refa Firgiyanto $^{4}$, Mira Andriani ${ }^{5}$ \\ ${ }^{12345}$ Politeknik Negeri Jember \\ E-mail: mayaweka@polije.ac.id
}

Article History:

Received: September 2021

Revised: September 2021

Accepted: Oktober 2021

Available online: Desember 2021

\section{Keywords:}

Kader, Pengetahuan, Posyandu, Stunting
Abstract: Dalam profil Dinas kesehatan Kabupaten Jember Tahun 2016 masih ditemukan balita Bawah Garis Merah (BGM) sebanyak 1.825 balita. Kecamatan Arjasa merupakan salah satu Kecamatan di Kabupaten Jember yang memiliki jumlah balita gizi buruk tertinggi sebanyak 87 balita $(3,8 \%)$. Peran kader di Posyandu "Manggis $18,15 \mathrm{~A}$, dan 15 " belum optimal karena masih memiliki pengetahuan yang kurang terkait stunting dan cara pencegahannya. Kader juga belum berperan aktif dalam pengolahan Pemberian Makanan Tambahan (PMT) balita. Salah satu bahan makanan lokal yang baik untuk PMT adalah daun kelor (Moringa Oleivera). Dengan demikian diperlukan peningkatan pengetahuan kader posyandu dalam pembuatan PMT berbahan dasar kombinasi kelor dan susu sapi sebagai upaya percepatan pencegahan stunting. Kegiatan dilakukan dengan memberikan penyuluhan tentang tata laksana stunting. Kegiatan pelatihan pembuatan PMT berbahan dasar kombinasi kelor dan susu sapi juga dilakukan dengan menghasilkan produk YOKE (Yoghurt Kelor) dengan varian rasa original, pandan dan the hijau. Selain itu juga terdapat produk nugget ayam maronggi. Perlu untuk merancang program lanjutan sebagai tindak lanjut dari kegiatan 
ini yaitu pelatihan kewirausahaan produk PMT bagi untuk mendukung ekonomi kader Posyandu.

\section{Pendahuluan}

Sebelum adanya Covid-19, Indonesia juga sudah menghadapi masalah gizi yang tinggi. Lebih dari tujuh juta anak balita mengalami stunting. Stunting adalah kondisi dimana balita memiliki panjang atau tinggi badan yang kurang jika dibandingkan dengan umur. Kondisi ini diukur dengan panjang atau tinggi badan yang lebih dari -2SD median standar pertumbuhan anak dari WHO (Kemenkes RI, 2018). Penurunan prevalensi stunting pada balita merupakan sasaran pokok RPJMN 2020-2024 dimana target prevalensi stunting (pendek dan sangat pendek pada balita sebesar 19\% pada tahun 2024 (Menteri Kesehatan Republik Indonesia, 2020b). Tren prevalensi stunting pada balita dari 37,2\% (Badan Penelitian dan Pengembangan Kesehatan, 2013) turun menjadi 30,8\% (Kementerian Kesehatan Republik Indonesia, 2018) dan 27,7\% (Menteri Kesehatan Republik Indonesia, 2020b). Lebih jauh lagi, dalam Peraturan Menteri Kesehatan No. 21 tahun 2020 tentang rencana strategis kementerian kesehatan tahun 2020-2024, target penurunan stunting 14\% pada 2024 (Menteri Kesehatan Republik Indonesia, 2020b). Jika dibandingkan dengan capaian tahun 2019, prevalensi stunting masih jauh dari target dan dibutuhkan upaya percepatan penurunan stunting.

Stunting dapat menghambat pertumbuhan ekonomi dan menurunkan produktivitas pasar kerja, berakibat hilangnya 11\% PDB serta mengurangi pendapatan pekerja dewasa hingga $20 \%$. Selain itu, stunting juga dapat berkontribusi pada melebarnya kesenjangan, sehingga mengurangi $10 \%$ dari total pendapatan seumur hidup dan menyebabkan kemiskinan antar generasi (Saputri \& Tumangger, 2019). World Food Programme (WFP) dalam studi tentang biaya pangan Indonesia 2017, menyatakan bahwa secara nasional hanya $62 \%$ rumah tangga Indonesia yang dapat membeli pangan bergizi dikarenakan hambatan daya beli rumah tangga miskin, dan program subsidi pemerintah untuk masyarakat miskin belum memenuhi standar kecukupan gizi.

Penyebab stunting adalah faktor multidimensi, seperti pemahaman orang tua mengenai pola asuh yang baik, kesehatan lingkungan serta kemampuan menyediakan gizi yang cukup masih rendah sehingga prevalensi stunting masih tinggi (Kementerian Perencanaan Pembangunan Nasional, 2020). Praktik pemberian makanan pada bayi dan balita seperti pemberian 
makanan pelengkap yang terbatas dalam jumlah, kualitas dan variasi kepada balita juga merupakan penyebab stunting (WHO, 2014); Hall et al., 2018). Kejadian stunting diawali dari kejadian underweight atau kekurangan energi kronis yang terjadi secara berkelanjutan sehingga bila tidak segera dilakukan penanganan maka anak akan mengalami stunting (Badan Penelitian dan Pengembangan Kesehatan, 2013).

Salah satu kelompok yang rentan mengalami masalah kekurangan gizi adalah balita. Gizi buruk pada balita sering dikaitkan dengan kurangnya energi dan protein dalam jangka waktu yang lama (Gebrezgi, 2019). Kurangnya konsumsi protein dapat meningkatakan terjadinya stunting 1,6 kali lebih besar daripada asupan protein yang cukup (Azmy U. \& Mundiastuti L., 2018). Salah satu penyebab stunting adalah rendahnya kualitas nutrisi mikro pada makanan, rendahnya asupan keragaman makanan dari sumber hewani, pemberian makanan tambahan yang rendah energi (Beal, Tumilowicz, Sutrisna, Izwardy, \& Neufeld, 2018). Upaya untuk memenuhi kebutuhan gizi anak dan mencegah stunting adalah dengan Pemberikan Makanan Tambahan (PMT) berupa jajanan atau snack sehat yang dapat membantu memenuhi kebutuhan gizi balita karena balita cenderung menyukai makanan yang manis (Permatasari, 2018). Upaya baru-baru ini untuk memerangi malnutrisi dengan meningkatkan kualitas makanan tambahan di negara berkembang adalah penggunaan bubuk daun kelor (Moringa Olivera) sebagai fortifikasi makanan (Boateng, Quarpong, Ohemeng, Asante, \& Steiner-Asiedu, 2019). Selain itu, anak-anak yang mengalami malnutrisi parah terbukti mengalami kenaikan berat badan yang signifikan ketika pemberi perawatan menambahkan daun kelor ke dalam makanan mereka (Sengev, Abu, \& Gernah, 2013). Tanaman kelor banyak ditemukan di daerah tropis dan merupakan sumber protein dan mikronutrien yang tinggi. Daun kelor mudah dipanen dan dikeringkan dengan dijemur dan dihaluskan untuk membentuk bubuk yang bisa disimpan dan digunakan di rumah tangga pedesaan (Boateng et al., 2019; Golden, 2009; WHO Child Growth Standards', 2009)

Dalam profil Dinas kesehatan Kabupaten Jember Tahun 2016 masih ditemukan balita Bawah Garis Merah (BGM) sebanyak 1.825 balita. Kecamatan Arjasa merupakan salah satu Kecamatan di Kabupaten Jember yang memiliki jumlah balita gizi buruk tertinggi sebanyak 87 balita $(3,8 \%)$ (Dinas Kesehatan Kabupaten Jember, 2017). Desa Kemuning Lor merupakan salah satu desa di Kecamatan Arjasa, kabupaten Jember yang telah menjadi desa mitra Politeknik Negeri Jember sejak 2019. Berdasarkan data profil Desa Kemuning Lor Jember, salah satu masalah kesehatan yang dihadapi adalah 
stunting. Pada tahun 2010, masih terdapat 1 balita gizi buruk, 21 balita bergizi kurang (Profil Desa kemuning Lor, 2020). Selanjutnya, berdasarkan Laporan Konvergensi Pencegahan Stunting Tingkat Desa terhadap Sasaran Rumah Tangga 1.000 HPK tahun 2019 di Desa Kemuning Lor terdapat 8 anak usia 023 bulan dimana hasil pengukuran tikar pertumbukan (deteksi dini stunting) berada pada resiko stunting/ kuning (25\%) dan terindikasi stunting/ merah $(37,5 \%)$.

Fasilitas Kesehatan yang dikelola dari, oleh, untuk, dan bersama masyarakat, guna memberdayakan masyarakat dan memberikan kemudahan kepada masyarakat dalam memperoleh pelayanan kesehatan dasar adalah Posyandu. Posyandu "Manggis 18" Dusun Darungan, Desa Kemuning Lor, Kecamatan Arjasa, Kabupaten Jember memiliki kegiatan utama meliputi kesehatan ibu dan anak; keluarga berencana; imunisasi; gizi; pencegahan dan penanggulangan diare. Upaya peningkatan peran dan fungsi Posyandu merupakan tanggungjawab semua komponen yang ada di masyarakat, termasuk kader. Peran kader dalam penyelenggaraan Posyandu sangat besar karena sebagai pemberi informasi kesehatan kepada masyarakat (Kesehatan, 2012). Selain kegiatan utama, Posyandu "Manggis 18" juga melaksanakan kegiatan pengembangan/pilihan yaitu Bina Keluarga Balita (BKB), Tanaman Obat Keluarga (TOGA) dan Bina Keluarga Lansia (BKL).

Saat ini masih terdapat balita kurang gizi di wilayah kerja Posyandu "Manggis 18". Inisiatif pembentukan Posyandu "Manggis 18" berasal dari ibu ketua RW dan beberapa tokoh masyarakat Desa Kemuning Lor. Hingga saat ini, Posyandu "Manggis 18" menempati pekarangan rumah ibu Andayani Dusun Darungan, Desa Kemuning Lor. Penentuan lokasi merupakan hasil kesepakatan dengan perangkat desa. Namun sejak adanya Covid-19 kegiatan Posyandu dilakukan dengan Posyandu Keliling ke rumah balita di wilayah kerjanya. Kader Posyandu "Manggis 18" adalah ibu-ibu anggota PKK yang dengan sukarela dan ikhlas bertugas membantu kelancaran pelayanan kesehatan, meskipun tidak menempuh pendidikan yang sesuai dengan bidang kesehatan dan pendidikan. Jumlah kader Posyandu "Manggis 18" sebanyak 5 orang yang diketuai oleh ibu Andayani. Keberadaan kader sering dikaitkan dengan pelayanan rutin di Posyandu. Sehingga seorang kader posyandu harus mau bekerja secara sukarela dan ikhlas melaksanakan kegiatan Posyandu dan menggerakkan masyarakat untuk mengikuti kegiatan Posyandu.

Latar belakang kader Posyandu "Manggis 18" rata-rata tamatan Sekolah Menengah Atas (SMA) menyebabkan mereka masih memiliki pengetahuan yang kurang terkait stunting dan cara pencegahannya. Kader 
hanya memiliki niat yang tulus untuk ikut berperan secara nyata dalam pertumbuhan anak balita agar mereka tidak menderita gizi kurang. Hal ini dibuktikan bahwa setiap dilakukan kegiatan Posyandu, selalu dilakukan pengukuran antropometri tubuh balita. Saat pandemi Covid-19 kader bersedia melakukan Posyandu Keliling. Namun fasilitas Posyandu "Manggis 18" tidak memiliki timbangan untuk bayi digital karena rusak. Mereka hanya memiliki timbangan bayi tradisional (dacin). Tidak memungkinkan bagi kader Posyandu untuk melakukan Posyandu Keliling dengan membawa dacin. Dengan demikian kegiatan penimbangan balita tidak berjalan dengan optimal.

Sejak berdiri tahun 1990 hingga sekarang Posyandu "Manggis 18" belum melakukan pemberian PMT secara rutin, kadang pemberian PMT tidak dilakukan. Hingga saat ini Posyandu "Manggis 18" belum memiliki produk olahan PMT dengan memanfaatkan potensi tanaman sekitar yang terstandar gizi dan teruji klinis. Hal ini karena Kader tidak terbekali oleh kemampuan bagaimana mengolah PMT menggunakan bahan lokal yang ada di lingkungannya. Hasil wawancara dengan kader Posyandu "Manggis 18" menunjukkan bahwa mereka belum pernah mengikuti kegiatan pelatihan dan seminar/workshop terkait pengolahan PMT karena mereka harus membayar mahal. Sedangkan pelatihan dari dinas pendidikan jarang diselenggarakan. Hal ini menunjukkan bahwa belum produktifnya kader Posyandu dalam pembuatan dan pemasaran produk PMT sebagai modal dalam pengelolaan Posyandu maupun peningkatan ekonomi kader di era pandemic Covid-19 ini. Selain itu dapat dilihat bahwa belum terciptanya manajemen Posyandu yang sehat dan terpadu yang memadukan kombinasi peningkatan kesehatan dan keuangan. Selain itu, Bahan makanan lokal yang baik untuk PMT adalah daun kelor (Moringa Olivera) (Permatasari, 2018). Daun kelor merupakan bahan makanan dengan nilai gizi tinggi terutama zat besi. Zat besi dalam 100gram daun kelor yaitu $7 \mathrm{mg}$, apabila ditepungkan menjadi 28,2 mg. Kadar protein dan zat besi pada makanan olahan kelor dapat memenuhi standar PMT balita (Sari \& Adi, 2017). WHO menganjurkan agar anak-anak dan balita yang masih dalam masa pertumbuhan untuk mengonsumsi daun kelor karena berkhasiat untuk meningkatkan kekebalan tubuh dan mencegah gizi buruk.

Moringa Olivera semua bagian pohonnya dapat dimanfaatkan. Sayuran ini mudah didapat dan sudah lama dikonsumsi masyarakat Desa Kemuning Lor, Jember. Kandungan senyawa Moringa Olivera diteliti dan dilaporkan oleh While Gopalan, et al. dan dipublikasikan dalam buku All Thing Moringa (Santi, Triwidiarto, Syahniar, Firgiyanto, \& Andriani, 2020) bahwa seluruh bagian tanaman Moringa Oleifera dapat dimanfaatkan untuk 
pengembangan, menjaga dan meningkatkan kualitas kesehatan manusia terutama asupan gizi. Kandungan protein dalam daun segar Moringa Olivera per 100 gram adalah 6,7 gram. Sari daun Moringa Olivera sangat berpotensi sebagai bahan PMT bernutrisi. Olahan yang memungkinkan adalah pengolahan kombinasi kelor dan susu sapi.

Bentuk camilan sehat bergizi yang kaya protein hasil kombinasi olahan kelor dan susu sapi misalnya YOKE (yoghurt kelor) dan nugget ayam maronggi. Sebagaimana diketahui balita tidak tertarik jika harus makan sayur, namun akan gemar sekali dengan camilan manis maupun makanan berbentuk nugget. Dengan semua permasalahan ini berjalannya Posyandu "Manggis 18" terkesan apa adanya seperti pepatah "hidup segan mati tak mau". Hal ini berdampak pada berkurangnya tingkat kepercayaan masyarakat untuk berpartisipasi di Posyandu "Manggis 18". Jika kader dan tenaga kesehatan tidak mempunyai keterampilan dalam pelayanan di Posyandu maka akan mempengaruhi ketidakaktifan ibu balita untuk kunjungan ke posyandu dan pemanfaatan pelayanan kesehatan lainnya terutama memperbaiki masalah gizi pada balita. Selain itu, adanya pelatihan pembuatan PMT berbahan dasar kombinasi kelor dan susu sapi diharapkan berdampak positif terhadap penurunan kasus stunting.

\section{Metode}

Dalam rangka meningkatkan pengetahuan kader Posyandu dalam pembuatan PMT berbahan dasar kombinasi kelor dan susu sapi sebagai upaya percepatan pencegahan stunting maka dilakukan dengan metode yang sistematis dengan langkah-langkah sebagai berikut:

1. Ceramah materi pelatihan tentang:

a. Definisi stunting.

b. Penyebab stunting.

c. Upaya pencegahan stunting.

d. Pengertian PMT (Pemberian Makanan Tambahan).

2. Praktek membuat PMT (Pemberian Makanan Tambahan) berbahan dasar kombinasi kelor dan susu sapi dengan jenis makanan YOKE (yoghurt kelor) dan nugget ayam maronggi.

3. Sesi pertanyaan atau diskusi mengenai materi yang disampaikan. 


\section{Hasil}

\section{a. Perijinan dan Sosialisasi Kegiatan}

Sebelum dilakukan kegiatan pengabdidan kepada masyarakat, kegiatan diawali dengan melakukan perijinan dan sosialisasi kegiatan kepada salah satu pengurus Posyandu Manggis 18, Desa Kemuning Lor, Kab. Jember. Kegiatan ini disambut dengan antusias oleh pengurus Posyandu Manggis 18.

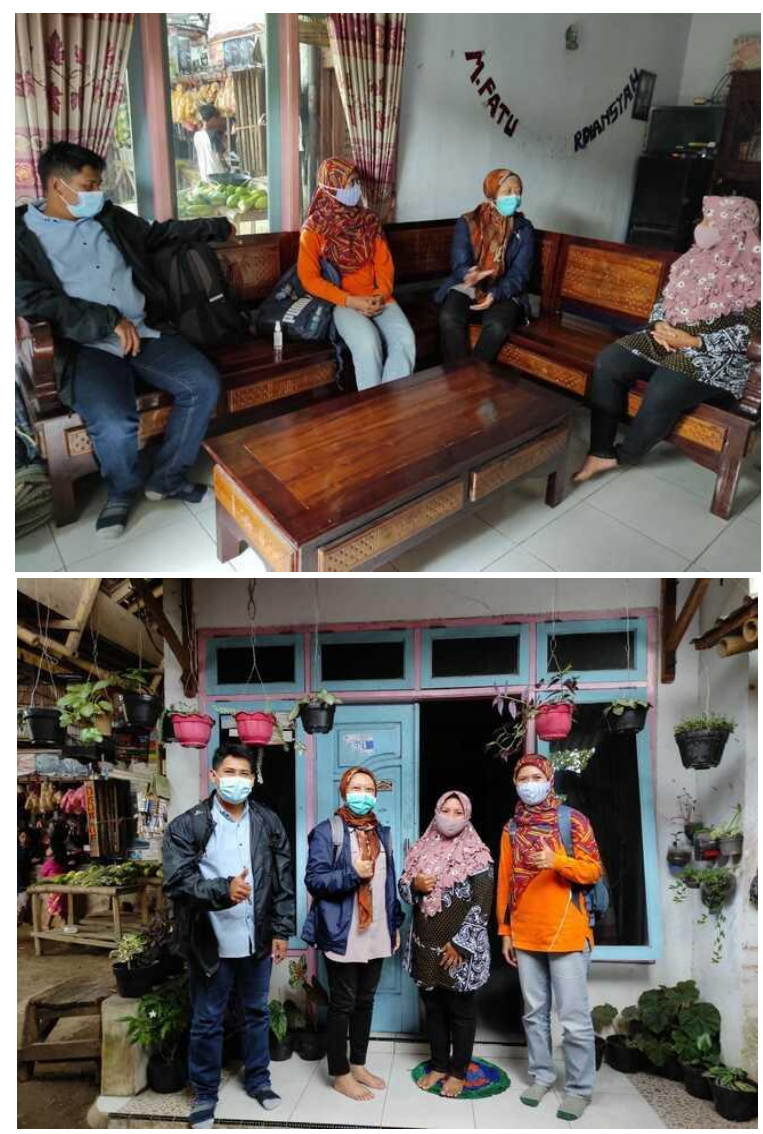

Gambar 1. Perijinan dan Sosialisasi Kegiatan kepada Salah Satu Penanggung Jawab Posyandu Manggis 18, Desa Kemuning Lor, Kab. Jember

\section{b. Peningkatan Pengetahuan Kader Posyandu tentang Stunting}

Setelah dilakukan perijinan dan sosialisasi, selanjutnya dilaksanakan kegiatan meningkatkan pengetahuan kader Posyandu dalam pembuatan PMT 
berbahan dasar kombinasi kelor dan susu sapi sebagai upaya percepatan pencegahan stunting. Kegiatan ini diawali dengan pemberian materi untuk peningkatan pengetahuan kader tentang stunting. Di dalam kegiatan tersebut materi yang disampaikan meliputi definisi stunting, penyebab stunting, upaya pencegahan stunting dan pengertian PMT (Pemberian Makanan Tambahan). Penyuluhan tentang stunting dilakukan secara daring melalui medis Zoom karena kegiatan dilakukan pada saat adanya aturan PPKM (Pemberlakuan Pembatasan Kegiatan Masyarakat) dari Pemerintah. Kegiatan ini diikuti oleh total 10 kader dari Posyandu Manggis 18, 15a dan 15, Desa Kemuning Lor, Kabupaten Jember.

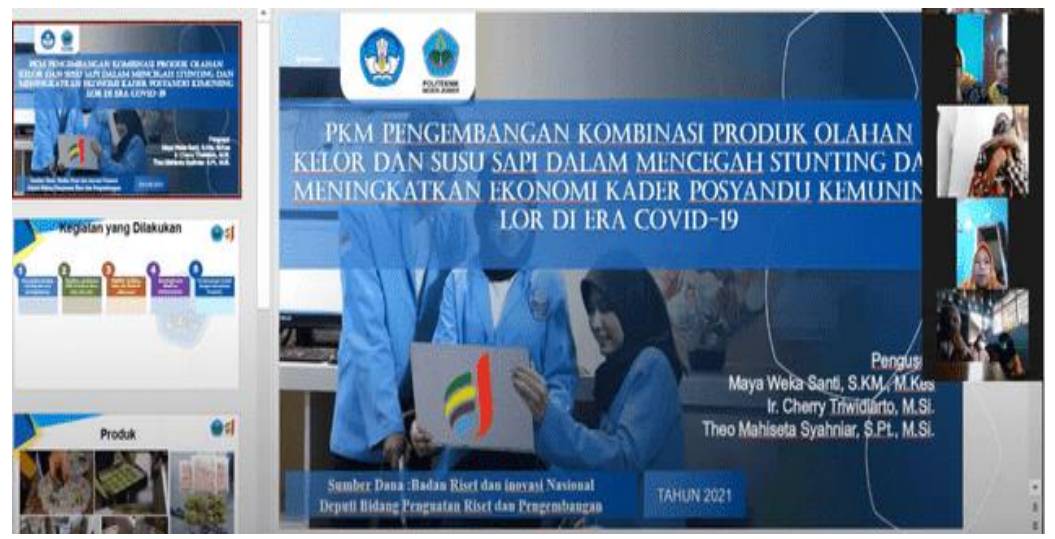

Gambar 2. Penyuluhan tentang Stunting dengan Kader Posyandu Manggis 18, 15a dan 15, Desa Kemuning Lor, Kab. Jember

Hasil menunjukkan bahwa kader sudah mengetahui tentang stunting. Stunting (pendek) merupakan kondisi dimana balita memiliki panjang atau tinggi badan yang kurang jika dibandingkan dengan umur. Anak balita dikatakan pendek apabila nilai Z-scorenya kurang dari -2SD (standar deviasi) dan sangat pendek apabila kurang dari -3SD (Dinas Kesehatan Provinsi Jawa Timur, 2018). Tabel Z-Score terdapat dalam Peraturan Menteri Kesehatan Republik Indonesia No 2 Tahun 2020 tentang Standar Antropometri Anak (Menteri Kesehatan Republik Indonesia, 2020). Pemberian materi pelatihan diberikan oleh salah satu tim pengabdian masyarakat. Pada saat pemberian materi dilaksanakan peserta aktif memberikan tanggapan dan tanya jawab. Namun kader belum mengetahui bahwa kelor merupakan bahan makan lokal 
yang kaya akan protein dan berpotensi untuk digunakan sebagai bahan dasar pembuatan PMT. Hasil tanya jawab juga menunjukkan bahwa selama ini kader belum pernah memperoleh pelatihan pembuatan PMT berbahan dasar kombinasi kelor dan susu sapi. Dengan demikian tim pengabdian kepada masyarakat melakukan program pelatihan pembuatan PMT berbahan dasar kombinasi kelor dan susu sapi.

\section{c. Pelatihan Pembuatan PMT Berbahan Dasar Kombinasi Kelor dan Susu Sapi}

Salah satu bahan makanan lokal yang baik untuk PMT adalah daun kelor (Moringa Oleivera) (Permatasari, 2018). Daun kelor merupakan bahan makanan dengan nilai gizi tinggi terutama zat besi. Zat besi dalam 100 gram daun kelor yaitu $7 \mathrm{mg}$, apabila ditepungkan menjadi 28,2 mg. Kadar protein dan zat besi pada makanan olahan kelor dapat memenuhi standar PMT balita (Sari \& Adi, 2017). Pada pelatihan pembuatan PMT berbahan dasar kelor ini dibuat produk yaitu YOKE (yoghurt kelor) dengan rasa original, pandan dan teh hijau serta nugget ayam maronggi.

\section{Tahap 1:}

Adapun bahan-bahan yang dibutuhkan untuk membuat yoghurt antara lain:

1. $1000 \mathrm{ml}$ susu segar. Kamu bisa menggunakan whole milk atau skim milk.

2. 2 sendok makan plain yoghurt (yoghurt dengan kandungan bakteri yang masih hidup/ bakteri probiotik).

Cara membuat Yoghurt:

1. Tuang $1000 \mathrm{ml}$ susu segar ke dalam panci dan panaskan menggunakan kompor dengan api kecil sambil diaduk perlahan, bisa juga menggunakan oven dengan temperatur hingga 85 derajat celcius. Saat proses pemanasan pastikan susu jangan sampai mendidih dan hangus pada bagian bawah. Proses ini bertujuan untuk mengubah struktur protein susu agar berubah menjadi padat. 
2. Setelah susu sudah cukup panas, angkat susu dan dinginkan dengan meletakkan panci ke dalam baskom atau wadah yang berisi air sambil diaduk secara perlahan hingga suhu susu mencapai 43 derajat celcius.

3. Saat mencapai temperatur yang diinginkan, tuangkan yoghurt plain dengan bakteri hidup ke dalam panci yang berisi susu tersebut. Aduk yoghurt dengan susu hingga rata secara keseluruhan.

4. Pindahkan susu yang sudah tercampur dengan yoghurt plain ke dalam stoples bersih. Tutup rapat sehingga tidak menyediakan ruang udara bisa masuk agar proses inkubasinya berjalan dengan sempurna.

5. Saat proses inkubasi terjadi, diamkan cairan yoghurt agar bakteri tumbuh dan berkembang. Pastikan temperatur saat proses inkubasi terjadi ada pada 38 derajat celcius. Proses ini akan memakan waktu selama 7 jam. Semakin lama didiamkan maka tingkat keasaman akan semakin tinggi dan tekstur akan menjadi lebih kental.

6. Setelah mendiamkan selama 7 jam atau lebih, dinginkan yoghurt yang telah mengental ke dalam lemari es beberapa jam sebelum dikonsumsi agar yoghurt lebih awet atau menambahkan waktu sebelum kadaluarsa sebanyak 1 hingga 2 minggu.

7. Jika ingin membuat yoghurt lagi, pisahkan beberapa sendok yoghurt original pertama Anda ke dalam wadah kecil. inilah kelak yang menjadi starter jika Anda hendak membuat yoghurt lagi, tanpa perlu membeli bibit baru.

\section{Tahap 2:}

Cara membuat minuman YOghurt KElor (YOKE):

Bahan-bahan:

1. $1000 \mathrm{ml}$ yoghurt plain

2. 1 ltr air utk merebus gula

3. 300 gr gula pasir

4. Perasa makanan (sesuai selera) / Sari daun kelor (daun kelor di blanching lalu di blender dan disaring) 
Langkah-langkah:

1. Pertama, membuat larutan gula. Siapkan panci, masukkan gula pasir Dan air lalu masak sampai mendidih dan gula larut. Matikan kompor, biarkan air gula dingin. Setelah dingin siap di gunakan.

2. Masukkan air gula ke dalam yoghurt secara bertahap sampai kekentalan yang di inginkan. Aduk-aduk supaya merata.

3. Yoghurt siap di beri sari (air) daun kelor atau perasa coklat, perasa buah-buahan atau buah asli sesuai selera. Setelah di beri perasa minuman yoghurt pun siap di nikmati.

4. Bahan pendukung: Botol plastik, Thinwall bulat, label.

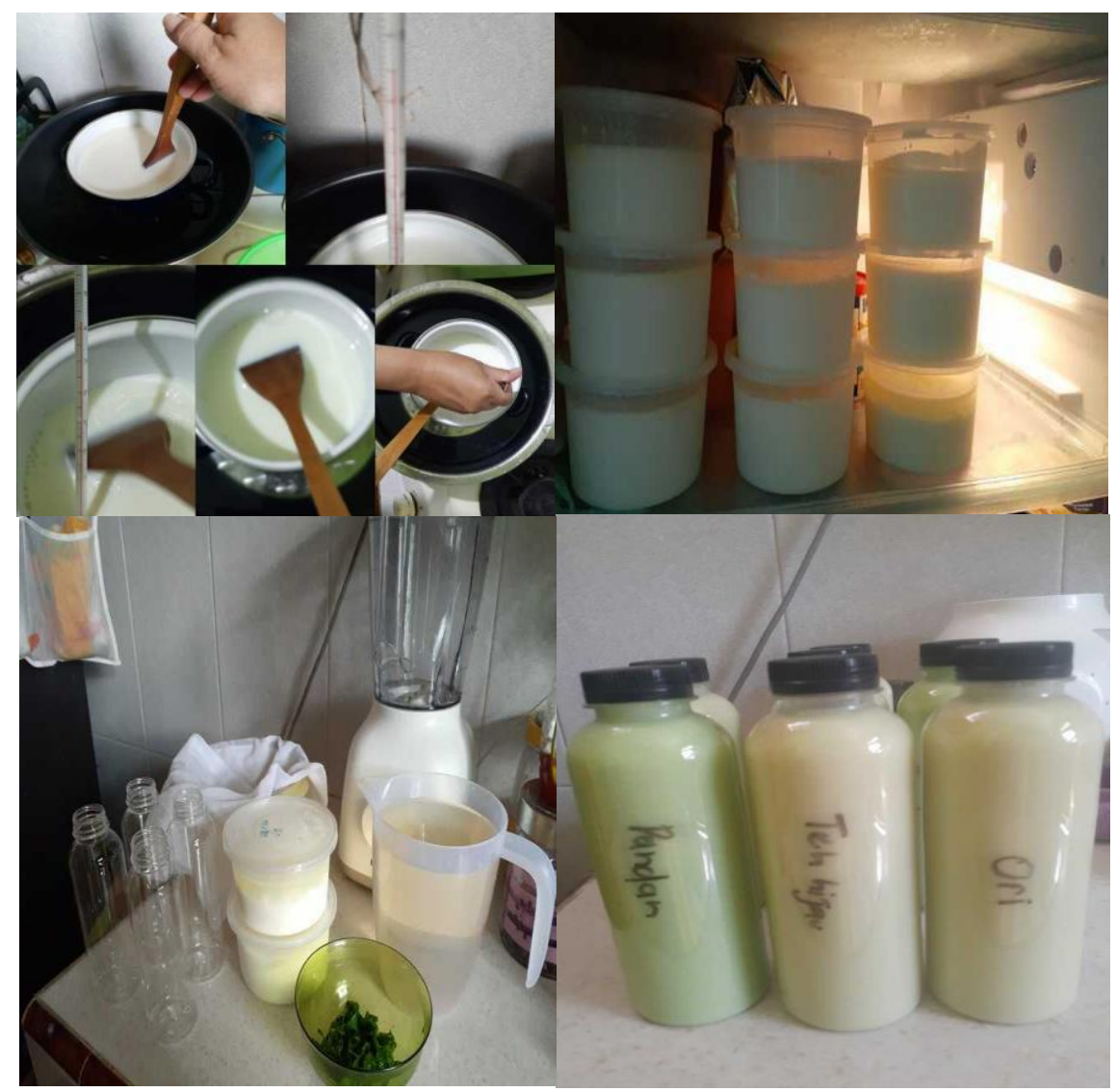

Gambar 3. Produk YOKE (Yoghurt Kelor) 
Bahan-bahan yang dibutuhkan untuk membuat nugget ayam maronggi adalah sebagai berikut:

1. Adonan Nugget: daging ayam fillet tanpa tulang 200gr; daun kelor 50 gr (di blanching/ dikukus \pm 5 menit; tepung terigu 50gr; tepung maizena 50gr; telur ayam 1 butir; bawang putih 2 siung; bawang merah 2 siung; lada / merica halus 1gr; garam 3gr; gula pasir 5gr; kaldu jamur $1 / 2$ sachet.

2. Adonan pelapis: tepung terigu 90gr; tepung maizena 60gr; tepung beras $65 \mathrm{gr}$; baking powder 10gr; lada / merica halus 5gr; garam 7-5gr; air $250 \mathrm{ml}$; tepung panir secukupnya.

Cara membuat nugget ayam kelor:

1. Kukus terlebih dahulu daun kelor selama kurang lebih 5 menit. Kemudian blanching makanan direndam dalam air yang mendidih dan dicelupkan ke dalam air es atau dialiri air dingin Langsung masukkan air dingin (air es) agar daun kelor tidak terlalu matang. Kemudian blender daun kelor hingga halus.

2. Pisahkan daging ayam dari tulang dan kulit (di fillet), kemudian daging ayam potong kecil-kecil.

3. Masukkan kedalam chopper (penggiling daging): daging ayam fillet beserta 1 butir telur, terigu, maizena, garam, gula pasir, lada halus, kaldu jamur, bawang putih, bawang merah dan daun kelor. Giling hingga daging ayam hancur dan adonan menjadi kalis (tercampur rata). Jika tidak memiliki chopper, bisa dicincang atau digiling menggunakan blender.

4. Siapkan pinggan tahan panas (Loyang), olesi dengan minyak goreng atau alasi dengan plastik. Siapkan juga panci kukusan.

5. Masukkan adonan dalam pinggan (Loyang). Kukus hingga matang. Kira-kira 30 menit.

6. Keluarkan adonan dan biarkan hingga dingin.

7. Jika sudah dingin, potong-potong sesuai selera. 
8. Buat adonan pelapis dengan mencampur semua bahan kecuali tepung panir.

9. Gulingkan potongan nugget kedalam adonan pelapis yang sudah dibuat. Lalu gulingkan dalam tepung panir

10. Simpan sesaat dalam freezer. Hal ini bermanfaat supaya tepung panir lebih menempel kuat pada adonan.

11. Jika ingin menghidangkan, goreng adonan dalam minyak panas dan banyak dengan api kecil.
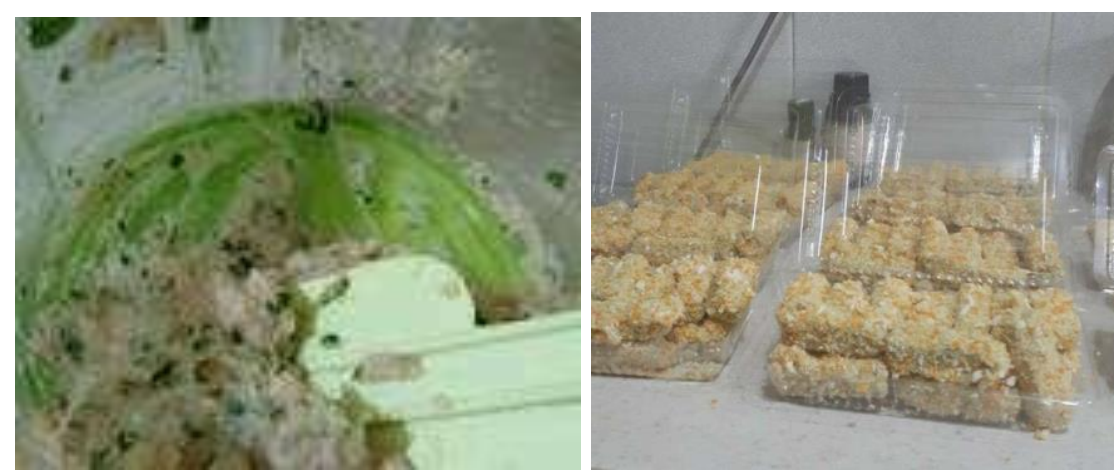

Gambar 4. Nugget Ayam Maronggi

\section{Diskusi}

Hasil pengabdian masyarakat di atas diperoleh temuan bahwa terjadinya peningkatan pemahaman kader sebagai sasaran pengabdian terkait tata laksana stunting dan cara pembuatan PMT berbahan dasar kombinasi kelor dan susu sapi. Hasil tersebut ditunjukkan dengan adanya peningkatan nilai dari hasil pretest dan posttest dengan nilai di atas 80 (nilai maksimal 100).

Tabel 1. Hasil Pretest dan Posttest Kader Posyandu

\begin{tabular}{ccc}
\hline Kader & Pretest & Posttest \\
\hline A & 50 & 90 \\
\hline B & 60 & 80 \\
\hline C & 70 & 100 \\
\hline D & 60 & 90 \\
\hline E & 60 & 90 \\
\hline F & 50 & 80 \\
\hline
\end{tabular}




\begin{tabular}{ccc}
\hline $\mathrm{G}$ & 50 & 90 \\
\hline Rata-rata & 57,15 & 88,57 \\
\hline
\end{tabular}

Hal ini sesuai dengan penelitian yang dilakukan oleh (Yulinda \& Fitriyah, 2018) bahwa penyuluhan dapat meningkatkan pengetahuan dan juga sikap para peserta. Artinya peserta penyuluhan dapat menerima pesan yang ingin disampaikan oleh narasumber. Dengan demikian jika ditinjau dari aspek pengetahuan kegiatan pengabdian memberikan dampak terhadap peningkatan pemahaman dan kemampuan pembuatan PMT berbahan dasar kombinasi kelor dan susu sapi. Kader ikut terlibat dalam pembuatan PMT seperti ketika membuat yoghurt, menghaluskan daging ayam dan kelor dengan blender, memasak susu sapi dan membuat adonan nugget. Dengan keterlibatan langsung kader dalam pelatihan pembuatan PMT menjadikan skill mereka menjadi terasah dalam membuat PMT ini.

Temuan lainnya sebagai dampak dari kegiatan pengabdian adalah tingginya respon peserta dalam mengikuti kegiatan pengabian kepada masyarakat. Dalam kegiatan penyuluhan tentang tata laksana stunting, kader secara aktif bertanya dan berdiskusi terkait kasus bayi dan balita stunting yang ada di wilayah kerjanya. Selain itu mereka juga aktif bercerita dan berbagi pengalaman terkait tata laksanan balita stunting yang dilakukan selama ini. Dengan demikian menunjukkan respon peserta kategori tinggi.

\section{Kesimpulan}

Dalam setiap pelaksanaan kegiatan dapat berjalan dengan lancar sesuai rencana sehingga dapat bermanfaat bagi peserta kegiatan. Termasuk dalam kegiatan pemberian materi dan pelatihan pembuatan PMT berbahan dasar kombinasi kelor dan susu sapi kepada kader Posyandu Manggis 18, 15a dan 15. Evaluasi yang dapat disampaikan berkenaan dengan pelaksanaan kegiatan ini adalah, mengingat tujuan yang ingin dicapai adalah tidak hanya memberi informasi, namun juga meningkatkan kemampuan kader Posyandu dalam membuat PMT untuk balita agar dapat membantu percepatan pencegahan stunting. Selain itu PMT hasil olahan berbahan dasar daun kelor dapat dikembangkan sebagai usaha rumah tangga demi menyokong ekonomi kader Posyandu Manggis 18, 15a dan 15. 


\section{Pengakuan/Acknowledgements}

Tim pengabdian kepada masyarakat dengan judul "Pengembangan Kombinasi Produk Olahan Kelor dan Susu Sapi dalam Mencegah Stunting dan Meningkatkan Ekonomi Kader Posyandu Kemuning Lor di Era Covid-19" mengucapkan terima kasih kepada para kader Posyandu Manggis 18, 15a dan 15, Desa Kemuning Lor, Kabupaten Jember dan Direktorat Riset Pengabdian Masyarakat (DRPM) atas dukungan pendanaan sehingga kegiatan ini dapat terlaksana dengan baik. Tidak lupa ucapan terimakasih kami sampaikan kepada Dinas Kesehatan Kabupaten Jember atas bantuan perizinan. Kegiatan pengabdian ini menjadi salah bentuk pemberdayaan masyarakat di sekitar Politeknik Negeri Jember untuk dapat mengatasi masalah yang sedang dihadapi. Serta Politeknik Negeri Jember membuktikan untuk dapat memanfaatkan ilmu pengetahuan secara benar demi kesejahteraan bersama.

\section{Daftar Referensi}

Azmy U., \& Mundiastuti L. (2018). Konsumsi Zat Gizi Pada Balita Stunting Dan Non-Stunting Di Kabupaten Bangkalan. Amerta Nutrition, 2(3), 292-298. Https://Doi.Org/10.20473/Amnt.V2.I3.2018.292-298

Badan Penelitian Dan Pengembangan Kesehatan 2013. (2013). Riset Kesehatan Dasar 2013. Https://Doi.Org/10.1126/Science.127.3309.1275

Beal, T., Tumilowicz, A., Sutrisna, A., Izwardy, D., \& Neufeld, L. M. (2018). A Review Of Child Stunting Determinants In Indonesia. Maternal And Child Nutrition, 14(4), 1-10. Https://Doi.Org/10.1111/Mcn.12617

Boateng, L., Quarpong, W., Ohemeng, A., Asante, M., \& Steiner-Asiedu, M. (2019).

Effect Of Complementary Foods Fortified With Moringa Oleifera Leaf Powder On Hemoglobin Concentration And Growth Of Infants In The Eastern Region Of Ghana. Food Science And Nutrition, 7(1), 302-311. Https://Doi.Org/10.1002/Fsn3.890

Dinas Kesehatan Kabupaten Jember. (2017). Profil Kesehatan Kabupaten Jember Tahun 2016. In Dinas Kesehatan Kabupaten Jember.

Dinas Kesehatan Provinsi Jawa Timur. (2018). Profil Kesehatan Provinsi Jawa Timur Tahun 2018.

Gebrezgi, D. (2019). Proximate Composition Of Complementary Food Prepared From Maize (Zea Mays), Soybean (Glycine Max) And Moringa Leaves In Tigray, Ethiopia. Cogent Food \& Agriculture, 5(1). Https://Doi.Org/10.1080/23311932.2019.1627779

Golden, M. H. (2009). Proposed Recommended Nutrient Densities For Moderately 
Malnourished Children. Food And Nutrition Bulletin, 30(3 Suppl. 1). Https://Doi.Org/10.1177/15648265090303s302

Hall, C., Bennett, C., Crookston, B., Dearden, K., Hasan, M., Linehan, M., ... West, J. (2018). Maternal Knowledge Of Stunting In Rural Indonesia. International Journal Of Child Health And Nutrition, 7(4), 139-145. Https://Doi.Org/10.6000/1929-4247.2018.07.04.2

Kemenkes Ri. (2018). Buletin Stunting. Kementerian Kesehatan Ri, 301(5), 1163 1178.

Kementerian Kesehatan Republik Indonesia. (2018). Hasil Utama Riskesdas 2018

Kesehatan. $\quad$ Riskesdas, $52 . \quad$ Retrieved $\quad$ From

Http://Www.Depkes.Go.Id/Resources/Download/Info-

Terkini/Materi_Rakorpop_2018/Hasil Riskesdas 2018.Pdf

Kementerian Perencanaan Pembangunan Nasional. (2020). Rencana Pembangunan Jangka Menengah Nasional 2020-2024.

Kesehatan, K. (2012). Ayo Ke Posyandu. In Transfusion Medicine And Hemotherapy. Https://Doi.Org/10.1159/000317898

Menteri Kesehatan Republik Indonesia. (2020a). Peraturan Menteri Kesehatan

Republik Indonesia No 2 Tahun 2020 Tentang Standar Antropometri Anak.

Menteri Kesehatan Republik Indonesia. (2020b). Rencana Strategis Kementerian Kesehatan Tahun 2020-2024. Retrieved From

Http://Journals.Sagepub.Com/Doi/10.1177/1120700020921110\%0ahttps://Doi

.Org/10.1016/J.Reuma.2018.06.001\%0ahttps://Doi.Org/10.1016/J.Arth.2018.0

3.044\%0ahttps://Reader.Elsevier.Com/Reader/Sd/Pii/S1063458420300078?To ken $=$ C039b8b13922a2079230dc9af11a333e295fcd8

Permatasari, N. E. Dan A. C. A. (2018). Daya Terima Dan Kandungan Gizi (Energi,

Protein) Gyoza Yang Disubstitusi Keong Sawah (Pilaampullacea) Dan Puree

Kelor (Moringa Oleifera). Daya Terima Kandungan Gizi, 62-70. Https://Doi.Org/10.20473/Mgi.V13i1.62

Profil Desa Kemuning Lor. (2020).

Santi, M. W., Triwidiarto, C., Syahniar, T. M., Firgiyanto, R., \& Andriani, M. (2020).

Peningkatan Pengetahuan Kader Posyandu Dalam Pembuatan Pmt Berbahan

Dasar Kelor Sebagai Upaya Percepatan Pencegahan Stunting. Dharma

Raflesia: Jurnal Ilmiah Pengembangan Dan Penerapan Ipteks, 18(2), 77-89.

Https://Doi.Org/10.33369/Dr.V18i2.12056

Saputri, R. A., \& Tumangger, J. (2019). Hulu-Hilir Penanggulangan Stunting Di Indonesia. Journal Of Political Issues, 1(1), 1-9. Https://Doi.Org/10.33019/Jpi.V1i1.2

Sari, Y. K., \& Adi, A. C. (2017). Daya Terima, Kadar Protein Dan Zat Besi Cookies

Substitusi Tepung Daun Kelor Dan Tepung Kecambah Kedelai. Media Gizi Indonesia, 12(1), 27-33.

Sengev, A. I., Abu, J. O., \& Gernah, D. I. (2013). Effect Of \&Lt;I\&Gt;Moringa 
Oleifera\&Lt;/I\&Gt; Leaf Powder Supplementation On Some Quality Characteristics Of Wheat Bread. Food And Nutrition Sciences, 04(03), 270275. Https://Doi.Org/10.4236/Fns.2013.43036

Who. (2014). Global Nutrition Targets 2025 Stunting Policy Brief.

Who Child Growth Standards. (2009). Developmental Medicine \& Child Neurology, 51(12), 1002-1002. Https://Doi.Org/10.1111/J.1469-8749.2009.03503.X

Yulinda, A., \& Fitriyah, N. (2018). Efektivitas Penyuluhan Metode Ceramah Dan Audiovisual Dalam Meningkatkan Pengetahuan Dan Sikap Tentang Sadari Di Smkn 5 Surabaya. Jurnal Promkes, 6(2), 116-128. Retrieved From Https://EJournal.Unair.Ac.Id/Promkes/Article/Viewfile/6439/5917 